\title{
Plant biological control agents as the basis for remediation and stabilization of agrobiocenoses
}

Kalamiyets E.I.

SRPA «Chemical Synthesis and Biotechnologies», Institute of Microbiology of NAS Belarus, Minsk, Belarus E-mail:kolomiets@mbio.bas-net.by

Key message. New approaches to diagnostics of plant diseases, development of composition and high-tech commercial forms of biopesticides were proposed for enhancement of their efficiency in remediation and stabilization of agrobiocenoses. Keywords: agrobiocenoses, biopesticides, diagnostics, microorganisms-antagonists

Application of biopreparations with phytoprotective action opens new frontiers to alleviate pesticide stress on agrobiocenoses, to yield prime-grade eco-safe farm products, to diminish dependence of agromanufacturers from supply of foreign chemicals. Theoretical and practical basis for design of biopesticides is the selection of superactive strains-antagonists and entomopathogens, elucidation of the type of metabolites showing antimicrobial and insecticidal activities, clarification of mechanisms governing antagonistic activity of introduced cultures, optimization of fermentation processes, elaboration of high-tech commodity forms of biopreparations. Both traditional selection methods and genome-editing techniques improving screening efficiency dozen- and hundred-fold are used to derive strains with elevated biological activity, growth rate, genetic stability, low sensitivity to biocenotic factors and eco-friendliness. Biopesticides derived from pre-selected microbial antagonists, like Fruitin (to control pathologies of berry and fruit cultivars), Phytoprotectin (to suppress diseases of vegetable crops), Betaprotectin (to counter clamp rot of sugar beet), Ecogreen (to combat pathologies of vegetables and green spice cultures), Baciturin, Bactosol, Xantrel ( to oppose pests and infections of potato and vegetable crops), Multiphage (to curb bacterial diseases of vegetable and fruit varieties), Polybact (to normalize soil microbial cenoses) occupied their appropriate niche at the home market ant possess a vast export potential. The key significance of elaborating microbial products for national economy is determined by low-cost manufacturing technology and cheap prices. The huge contribution into upgrading efficiency of biological control agents is made by the practiced diagnostics of phytopathogenic species using up-todate molecular-genetic identification methods (PCR, real-time PCR, multiplex PCR). New approaches in strategy of biopesticide elaboration will be aimed at perfecting the formulas and prolonging the storage terms of the developed high-tech commodity forms of the products.

\section{Биологические средства защиты растений как основа оздоровления и стабилизации агробиоценозов Коломиец Э.И. \\ ГНПО «Химический синтез и биотехнологии», Институт микробиологии НАН Беларуси, Минск, Беларусь}

\begin{abstract}
Аннотация. Предложены новые подходы к диагностике заболеваний растений, разработке композиционного состава и высокотехнологичных товарных форм биопестицидов для повышения эффективности их действия как агентов оздоровления и стабилизачии агробиоченозов.
\end{abstract}

Ключевые слова: агробиоченозы, биопестициды, диагностика, микроорганизмы-антагонисты.

Использование биопрепаратов с фитозащитным действием открывает перспективы снижения пестицидной нагрузки на агробиоценозы, позволяет получить высококачественную экологически чистую сельскохозяйственную продукцию, уменьшает зависимость агропромышленного комплекса от импорта агрохимикатов. Теоретической и практической основой создания биопестицидов является селекция высокоактивных штаммов микроорганизмовантагонистов и энтомопатогенов, выяснение природы метаболитов с антимикробной и энтомоцидной активностями, установление механизмов антагонистического действия потенциальных интродуцентов, оптимизация ферментационных процессов, разработка высокотехнологичных товарных форм. Для получения штаммов с высокой биологической активностью, скоростью роста, генетической стабильностью, низкой чувствительностью к биоценотическим факторам и безвредностью для окружающей среды используются как традиционные методы селекции, так и методы «редактирования» генома, повышающие эффективность селекционных работ в десятки и сотни раз. Разработанные на основе отселектированных штаммов микроорганизмов-антагонистов биопестициды Фрутин (для контроля возбудителей болезней ягодных и плодовых культур), Фитопротектин (для защиты овощных культур от болезней), Бетапротектин (для борьбы с кагатной гнилью сахарной свеклы), Экогрин (для защиты овощных и зеленных культур от болезней), Бацитурин, Бактосол и Ксантрел (для защиты картофеля и овощных культур от вредителей и болезней), Мультифаг (для борьбы с бактериозами овощных и плодовых культур), Полибакт (для оздоровления микробоценозов почв) нашли свою нишу на внутреннем рынке и имеют экспортный потенциал. Экономическая значимость для республики разработки микробных препаратов связана с малозатратной технологией их получения и низкой стоимостью. Большой вклад в повышение эффективности биологических средств защиты растений вносит практикуемая нами диагностика фитопатогенных микроорганизмов с использованием современных молекулярно-генетических методов (ПЦР, ПЦР в реальном времени, мультиплексная ПЦР). Новые подходы в разработке биопестицидов связаны с совершенствованием их композиционного состава и увеличением сроков хранения путем создания высокотехнологичных товарных форм. 